\title{
宿題報告
}

\section{3. 悪性腫瘍における高Ca血症一ATLを中心に一}

\section{江藤 澄哉}

Key words：高カルシウム, 悪性腫瘍, 成人 T細胞白血病

はじめに

悪性腫瘍において，高頻度に高カルシウム (Ca) 血症を合併し (malignancy associated hypercalcemia : MAH)，多彩な臨床症状を呈し， 時にはこの高Ca血症が直接死因とさえなり得 るが，特効薬が市販された現在でも実地臨床の 場で，意外にこの事実が見逃されている場合が 多い。このMAHの高Ca血症は腫瘍細胞から産 生・分泌される骨吸収刺激因子（bone resorption stimulating factor;BRSF) によって惹起 されるまた，悪性腫瘍における高Ca血症に 対する治療についても，従来法に加え，新しい 治療法が開発され，実用段階に入った。

成人T細胞白血病（ATL）の高Ca血症の発 症頻度およびその程度は扁平上皮癌を中心とす る固形癌に比し，極めて高い．この違いは後述 するように，主要なBRSFであるPTHrP（parathyroid hormone related protein:PTH関連蛋 白）のみで説明することは不可能であり，その 理由につき，我々は長年にわたって検討してき た。本稿では当教室でATLにおける高Ca血症 につき得られた成果につき，詳述し，MAHの 基礎的・臨床的意義についても簡略に言及す る.

\section{MAHの頻度・分類・発症機序}

\section{1) 頻度}

表1に示すように我々の経験したATLにお けるMAHの頻度は，他の悪性腫瘍のそれに比 し極めて高度である。ちなみに，癌センターの 成績は，13,550人という多数例の検索から得ら れた成績である゙。 。た，高Ca血症を来す原因 疾患は多彩であるが頻度の上からみると原発性 副甲状腺機能立進症とMAHで全体の90\%を占 め, しかも，その比率は $1: 1$ と同等である。 すなわち，かくの如く，MAHは頻繁にみられ る病態であることを認識されたい。

2）分類

$\mathrm{MAHの}$ 高Ca血症は, 腫瘍細胞から産生・分 泌されるBRSFがホルモンの如く血中をめぐっ て破骨細胞の形成・活性化により骨吸収を起こ し，Caが血中に遊出し，また，腎の尿細管か らのCaイオンの再吸収を促すHHM（humoral hypercalcemia of malignancy) と，骨転移や多

表 1，恶性腫宣における高 Ca 血症の頻度

\begin{tabular}{ll} 
1. 成人 $\mathrm{T}$ 細胞白血病 & $70 \%$ \\
2. 多発性骨髄腫 & $15 \% *$ \\
3. 食道癌 & $13 \%{ }^{*}$ \\
4. 咽頭癌 & $11 \%{ }^{*}$ \\
5. 腎癌 & $11 \% *$ \\
\hline
\end{tabular}

*:国立がんセンター症例 
表 2. HHM と LOH の比較

\begin{tabular}{l|c|c}
\hline & $\mathrm{HHM}$ & $\mathrm{LOH}$ \\
\hline 頻度 & $80 \%$ & $20 \%$ \\
\hline 機序 & 体液性·全身性 & 局所性 \\
\hline 惹起因子 & PTHrP & IL-1, IL-6, TNF, \\
& (PTH · 活性型 VD は稀) & TGF 等 \\
\hline 疾患 & 各種固形癌 & 多発性骨髄腫 \\
& 成人 T 細胞白血病 & 骨転移 \\
\hline
\end{tabular}

発性骨䯣腫などで見られる局所的なBRSFの破 骨細胞活性化によって骨融解が促進される LOH (local osteolytic hypercalcemia) なる病 態に大別される（表 2 ）. 前者の原因物質とし てはPTHrPが主要なものと考えられているの に対し,LOHの場合にはIL(interleukin)-1, IL-6, TNF (tumor necrosis factor), TGF (transforming growth factor) などのサイトカインが主た るBRSFであると考えられてきた．HHMとLOH の比率は大凡 $8: 2$ と考えて良い。しかしなが ら, 最近では, 骨転移や多発性骨髄腫などで PTHrPの関与すること, 多くの腫瘍では, PTHrPとサイトカインを同時に産生すること, ATLをふくめて，HHMの範疇にはいると考え られてきた疾患でも局所的な骨融解像をみとめ ることなどから，HHMとLOHはかならずしも
判然と区別出来ないと考える方向にある. しか し, なお, MAHのうち, HHMと考えられる症 例では高頻度に血中PTHrP值の高値を認め, PTHrPの測定が可能になって，高Ca血症の鑑 別診断が容易になった.ATLをふくめた各種 疾患のC - 端PTHrPの測定值を図 1 に示す. 悪 性腫癔の高Ca血症群ではほほ全例で血清 PTHrPは高值をしめしているが, 非高Ca血症 の悪性腫湟でも血清PTHrPは高值（陽性）を 示すことがあり，かかる症例はのちに高Ca血 症群に移行し, PTHrP值の测定は高Ca血症発 症の予知にも有用である.ATLでの検討では 血中 · 尿中PTHrP值はsmouldering型, 慢性型 では正常範囲にとどまるが，急性型・リンパ腫 型では多くの症例で上昇する。ちなみに，ATL と他の悪性腫湯との間にはPTHrP值には特に 差がなく,ATLにおける高Ca血症の高頻度発 現をPTHrPだけで説明することは不可能であ ることを再度, 強調したい、なお，C端PTHrP はきわめて安定で，採血・保存に当たって特別 の注意を要しないが, 唯一の欠点は血中クレア チニン值が $2.0 \mathrm{mg} / \mathrm{dl}$ 越える腎障害では見掛け 上の高值を示すことであり，最近では比較的， 腎障害の影響を受けないintact-PTHrPが測定に 用いられることが多い (表 4 参照).

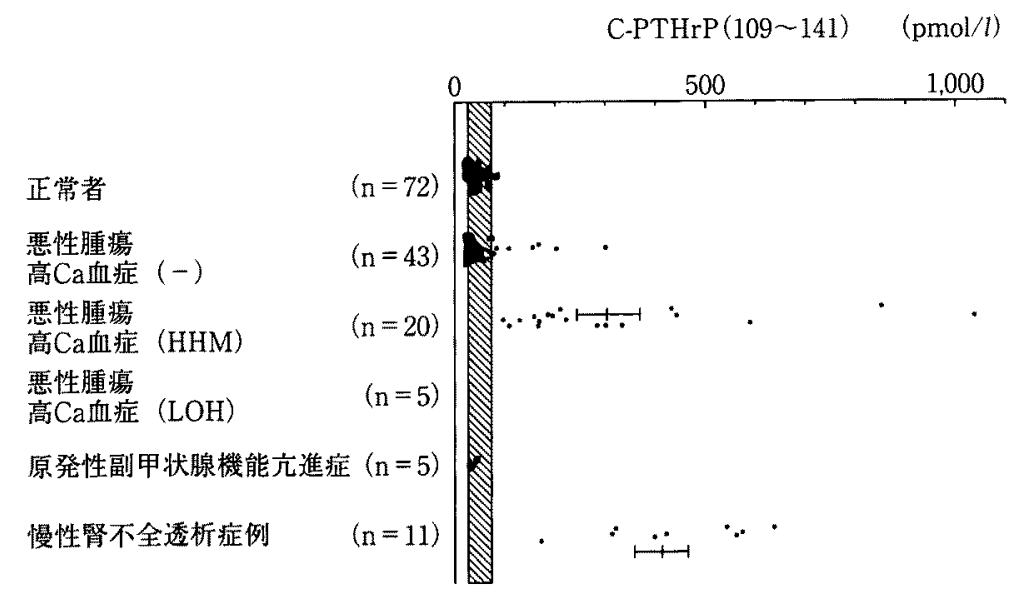

図 1.各種疾患における血清C-端PTH値 


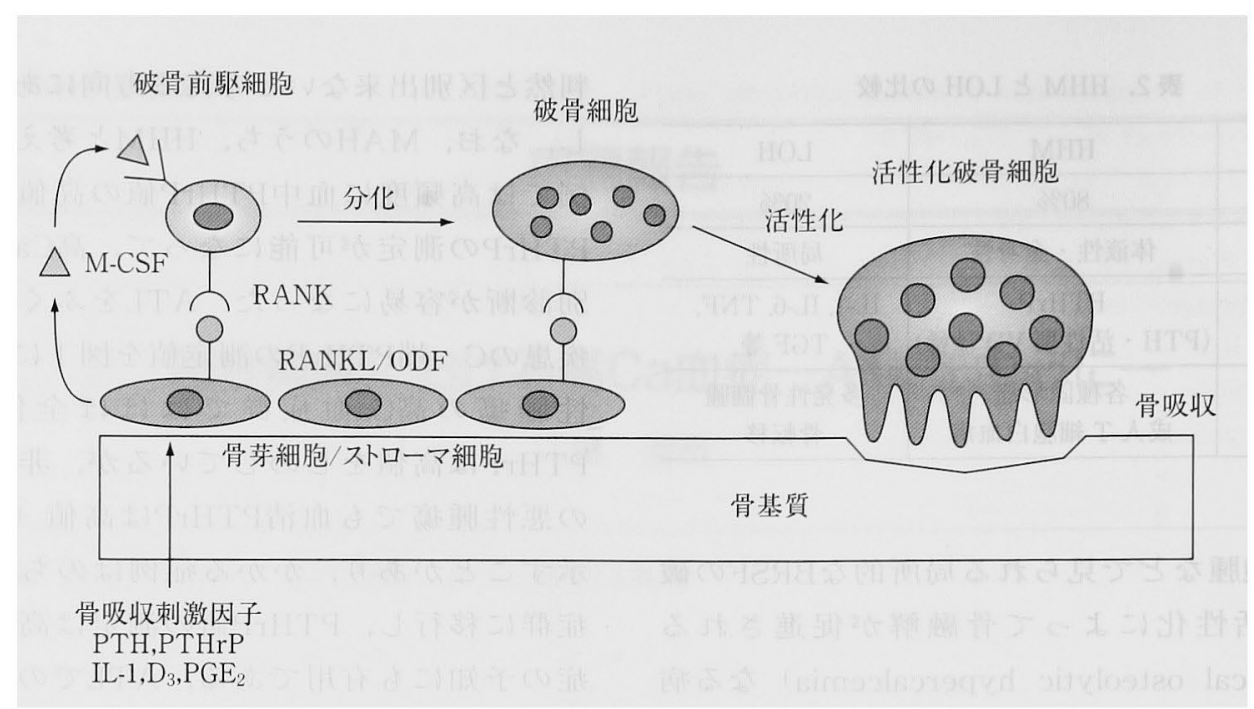

図 2．骨芽細胞による破骨細胞の分化㧍よび活性化の機序 RANKL/ODF：破骨細胞分化誘導因子, RANK：RANKL/ODF受容体

\section{3）BRSFによる骨吸収の発症機序}

骨吸収は血液幹細胞より分化した破骨細胞に よって行なわれるが, 破骨細胞の形成・活性化 には骨形成に関与する骨芽細胞の存在が必須で ある.すなわち, 骨芽細胞で産生される破骨細 胞分化誘導因子 (TRANCE/ODF/RANKL)が, 破骨細胞の形成に重要な役割をはたす ${ }^{2 \sim 5)}$. PTHrPやサイトカイン等のBRSFによる骨吸収 機序を図 2 に示す。これらBRSFは，まず骨芽 細胞に作用し, 破骨細胞分化誘導因子の産生お よび細胞膜上への発現を誘導する. 次いで, こ の分化誘導因子は破骨前駆細胞や破骨細胞との 接触を介してそのレセプター（RANK）と結合 して破骨細胞の形成・活性化を生じ, 骨吸収に つながる。

一方, 最近, BRSFが骨芽細胞を介さず, 直 接的に破骨細胞の形成・活性化に関与すること も報告された。すなわち, Jimiらは破骨細胞に IL-1レセプターが存在し, IL-1の結合が直接, 破骨細胞を活性化すること和, Kobayashiらは TNF $\alpha$ が破骨細胞前駆細胞に直接, 作用して破 骨細胞に分化させること音を報告している.

\section{ATLにおける高Ca血症}

\section{1) 病型別発症頻度 - 各種BRSFとの関連}

当科受診のATL85名を検討したところ, 慢 性型, くすぶり型では高Ca血症を認めないが, 高Ca血症は急性型では74\% (37/50), リンパ 腫型では50\%（9/18）で，両者をあわせて約70 \%の高率にのぼる. 患者の血中Ca值と各種 BRSFの血中レベルの相関をみると, intactPTHrP との相関係数は 0.39 と低值であるのに対 し, IL-1の值を反映する指標であるIL-1レセプ ター・アンタゴニスト（血中IL-1に付いては感 度の良い測定法は開発されていない) との相関 係数は $0.7, \mathrm{IL}-6$ とは0.6と高い相関関係を示し, ATLの高Ca血症にはPTHrPに加えてLOH関連 サイトカインが強く関与していることが示唆さ れる.

2） HTLV-I感染とPTHrP・IL-1産生

\section{(1) PTHrP}

高Ca血症を発症する悪性腫瘍のPTHrP遺伝 子発現機序についての詳細はなお不明である。 ただ，ATLにおいては，PTHrPが高度に産生 され ${ }^{8)}$, その遺伝子発現機序も詳細に検討され 
ているＡTL細胞におけるPTHrP-mRNAの発 現に関しては, Watanabeら"はHTLV-I（human T-cell leukemia virus type I） キャリアの 末梢単核球において，すでにPTHrP mRNAの 発現が認められること, HTLV-I ウイルスの遺 伝子産物であるTax蛋白がPTHrP遺伝子の発現 にかかわる転写因子を活性化することを証明し ている.さらに, IkedaらはPTHrP遺伝子の転 写調節にcAMP-protein kinase-A系の関与を示 唆し, 加えて, PTHrPの産生にはTax蛋白によ る転写因子NF-кBの活性化と, そのPTHrP遺

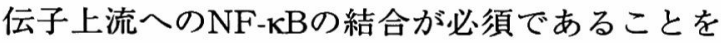
報告している ${ }^{10)}$. 最近, PTHrPの遺伝子の転 写にEts1の結合も不可欠であることが証明され ている ${ }^{11)}$.

また，Ikedaら ${ }^{12)}$ はTaxによって活性化され るIL-2・IL-2レセプターの関与にも注目し， PTHrP mRNAはIL-2によって増幅されること をATL株細胞MT-2を用いて明らかにした。 我々もIL-2が，患者より得られた新鮮ATL細 胞のPTHrP mRNA発現, 培養上清へのPTHrP の分泌を増加させることを確認した ${ }^{13)}$ ．すなわ ち, 生体内において, HTLV-I 感染によって活 性化されたT細胞はIL-2 の産生を増加し，この IL-2 がPTHrP産生を促し，高Ca血症惹起に関 与することが示唆される．なお，多発性骨髄腫 や固形癌の骨転移は原則的にLOHの範疇には いるが，局所的な骨融解を来すサイトカインが 腫瘍細胞でのPTHrP産生を促すとの報告 ${ }^{14)} も$ 多く, PTHrPはHHMだけでなくLOHにも関与 すると考える傾向にあるのは前述の通りであ る.

\section{(2) IL-I}

我々はMAHの発症にPTHrPの関与が推察さ れたとほほ同じ頃に，ATL細胞の培養上清中 に何らかのBRSFの存在することをbioassayで 見い出し ${ }^{15)}$ ，それがIL-1 であることを確認し た ${ }^{16)}$ 。この成績は, IL-1 がATLの高Ca血症発 症に大きく関与していることを示唆するもので

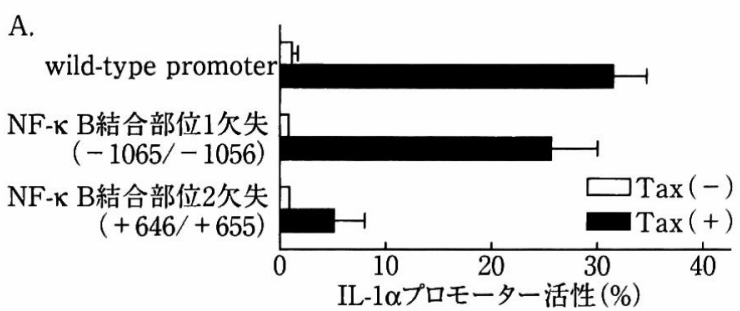

B.

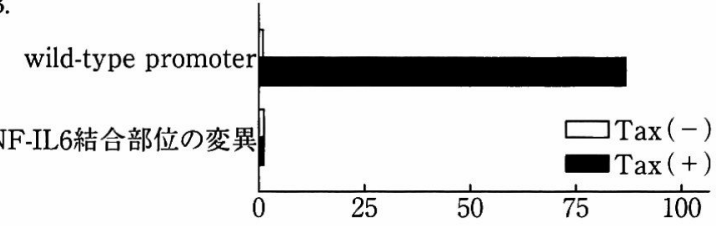

IL-1ßプロモーター活性 (比率)

図3.ATLにおけるTax蛋白によるIL-1 $\alpha(\mathrm{A})$, IL-1 （B）遺伝子の活性化

A.

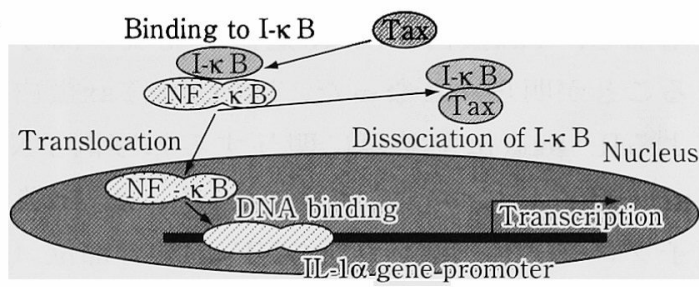

B.

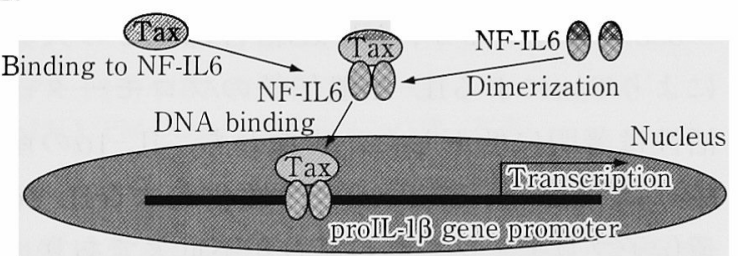

図4，ATLに掞けるTax蛋白によるIL-1 $\alpha(\mathrm{A})$ ， IL-1 $\beta$ （B）遺伝子の活性化機序

あり，その後の仕事につながって行った.

まず，我々はATLにおけるIL-1産生機序を 検討し, その結果, ATLでのIL-1 $\alpha$, IL-1 $1 \beta$ の 遺伝子発現にPTHrPと同様にHTLV-1 ウイル ス感染に伴って産生されるTax蛋白が関与する ことを確認したＩL-1 $\alpha$ 遺伝子発現とTaxとの 関係を検討するために，HTLV-I 非感染T細胞 白血病株細胞であるJurkat細胞に，CATベク ターにIL-1 $\alpha$ 遺伝子上流のプロモーターを組み 込み，Tax蛋白を高度に発現するべクターと共 


\section{HTLV-I 感染 \\ Tax蛋白(転写活性因子) 産生

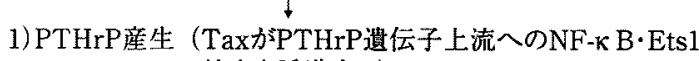 結合を誘導する)

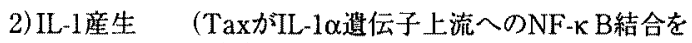 誘導する) \\ (TaxかiIL-1 $\beta$ 遗伝子上流へのNF-IL6結合を 誘導する)}

図 5.HTLV-1 産生Tax蛋白による骨吸収刺激因子 産生機序

に導入して（ATL細胞モデルと考えられる）IL$1 \alpha$ 遺伝子のプロモーター活性，すなわちIL- $1 \alpha$ 遺伝子の転写活性を検討した（図 3A）。Tax蛋 白発現べクター導入群のIL-1 $\alpha$ 遺伝子のプロ モーター活性は，Tax非導入群と比べて著明に 増加し，Tax蛋白がIL-1 $\alpha$ 遺伝子発現に関与す ることが明らかとなった。次いで, Tax蛋白に よるIL-10遺伝子発現に関与する転写因子NF-

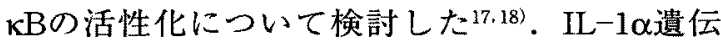
子プロモーターは 2 カ所のNF-kB結合部位（結 合部位 $1 ;-1065 /-1056$, 結合部位 $2 ;+646 /$ +655）を有するが, NF-kB結合部位 2 の欠失 によりTaxによるIL-1 $\alpha$ 遺伝子のプロモーター 活性は著明に低下した。すなわち，IL-1风の産 生にはTaxによるNF-KBの活性化およびIL-1 $\alpha$ 遺伝子プロモーターへの結合が不可久であり，

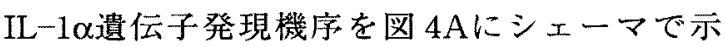
す.

IL-1 $\beta$ 遺伝子の発現についても同様の系で検 討を行なった. IL-1及遺伝子プロモーター活性 は, Tax蛋白発現ベクター導入で著明に上昇し, IL-1 3 遺伝子の転写, すなわち $\mathrm{L}-1 \beta$ 産生に もTax蛋白が関与することが判明した。さらに， $\mathrm{IL}-1 \beta$ 遺伝子の発現は，Taxによる転写因子NFIL-6の活性化が関与すること ${ }^{19)}$ ，さらに図 3Bに 示すように, TaxによるIL-1及遺伝子の転写活 性は，IL-1ßプロモーターのNF-IL-6の結合部 位を変異させると完全に消失することも確認し た (一部未発表データ)。すなわち, IL-1及の産

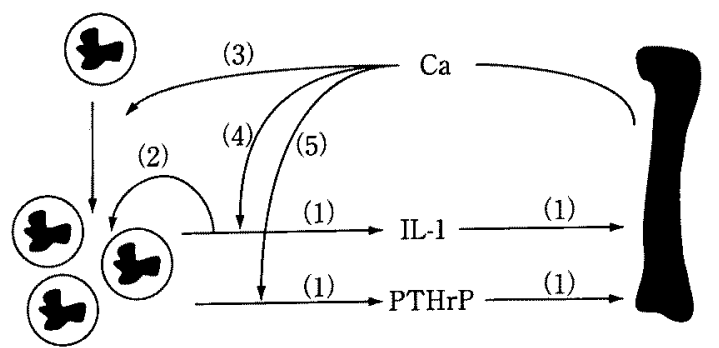

1)ATL細胞はIL-1・PTHrPを産生し, 骨吸収を促進する.

2)IL-1はATL細胞の増殖を促進する.

3) ATL細胞增殖は巽常高Ca条件下でむしろ増加する.

4)ATL緗胞加らのIL-1産生も異常高Ca条件下で増加する.

5)ATL細胞加のPTHrP産生も異常高Ca条件下で增加する。

図 6.ATLの高Ca血症におけるIL-1・PTHrPを介す る悪循環機構

生にはTaxによるNF-IL-6の活性化およびプロ モーター領域への結合が不可欠であり， $\Pi-1 \beta$ 遺伝子発現機序を図 $4 \mathrm{~B} に シ ェ ー マ て ゙$ 示す.

以上をまとめると, ATL細胞のIL-1 $\alpha, \beta$ 産生には，HTLV-I 感染の産物であるTax蛋白 が強く関与し, IL-1 遺伝子の転写と, それに 引き続くIL-1の産生にはIL-1遺伝子上流に結 合する転写因子のTax蛋白による活性化が必須 であると考えられる.また，その転写因子はIL-

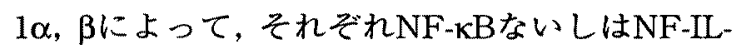
6と, 異なるものであることが推定される. PTHrPに関する成績とあわせて，ATLにおけ るBRSFの産生機序を図 5 に示す.

3）カルシウム濃度依存性のIL-1・PTHrPを 介する悪循環機構

我々は, ATL細胞・株細胞には極めて奇異 な性質のあること，すなわち，ATL細胞は， 通常の細胞では死滅する高Ca濃度の培盖条件 下でむしろ細胞増殖は增加し20)，またATL細 胞からのIL-1, IL-1レセプターの産生も同条件 下で增加することを見い出した ${ }^{21)}$.いずれの場

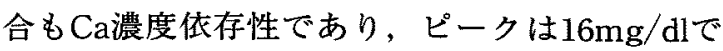
あった。一方, IL $-1 \alpha, \beta$ 自体もATL細胞増殖 を濃度依存性に增加させた ${ }^{22)}$. 以上の結果から ATLにおける高Ca血症発症にはIL-Iを介する 悪循環機構が存在すると考えられる。なおここ 
A.

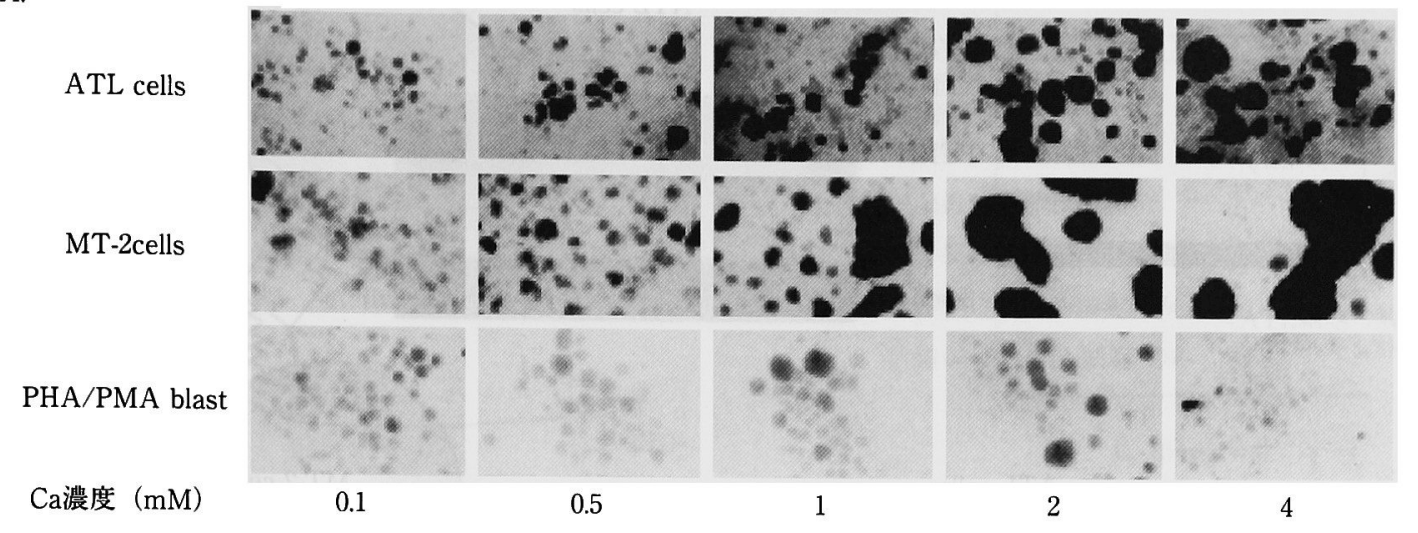

B.

ATL cells
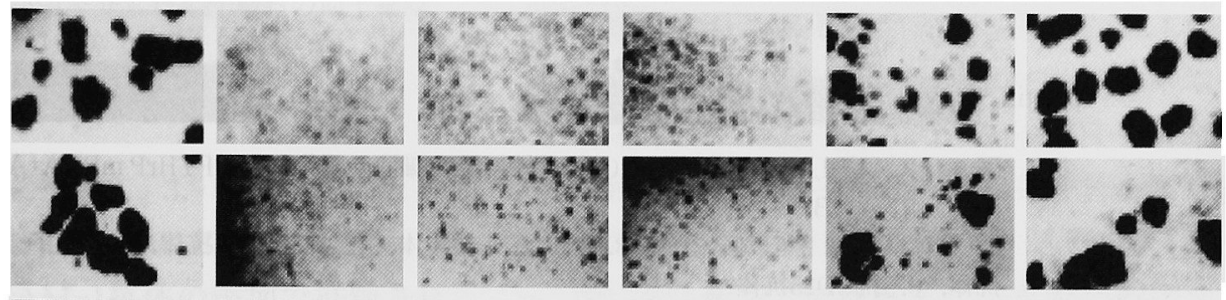

PHA/PMA blast

抗体（添加）
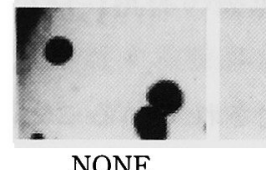

EDTA

\section{ICAM-1}

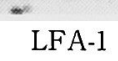

LFA-3

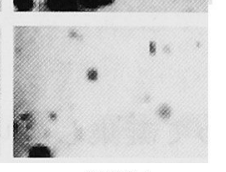

図 7.Ca依存性のATL細胞の凝集（A）とICAM-1/LFA-1を介するATL細胞の㠜集（B） ATL cells : 患者ATL細胞, MT-2 cells : ATL株細胞, PHA/PMA blast：幼弱化リンパ球（写真）

れらの現象はCa拮抗薬, カルモデュリン拮抗 薬により抑制されること, 細胞内Ca濃度と相 関することょり, 細胞内Caイオン関連シグナ ルの関与が推定される. その後, ATL細胞で PTHrP産生に対するCa濃度の影響についても 検討し, IL-1の場合と同様にCa濃度依存性に PTHrPのmRNA発現, 分泌ともに增加するこ とを証明した (未発表デー夕).すなわち, 上 記の悪循環機構にPTHrPも関与することが判 明した。

これらの成績を総合すると, 図 6 に示す如く ATL患者の生体内では, 1）ATL細胞からのILI・PTHrPの産生增加による骨吸収元進, 2) IL-I産生増加によるATL細胞の増殖, 3）高Ca
血症によるCa濃度依存性のATL細胞の増殖, 4) 5）Ca濃度依存性のIL-I, PTHrP産生増加等が 相俟って, 高Ca血症はさらに増悪するというILI・PTHrPを介するある種の悪循環機構の存在 が示唆される．実際に，患者のCa濃度とATL 細胞培養上清中のIL-I活性は正の相関をみと め, in vitroで得られた現象が生体内でも起こっ ているものと考えられる.

4）細胞接着を介した骨吸収刺激因子の産生

次に, ATL細胞同士, あるいはATL細胞と 骨芽細胞の細胞接着を介した骨芽細胞からの骨 吸収刺激因子の産生につき我々の成績を示す.

（1）Ca濃度依存性ATL細胞同士接着

従来から, ATL細胞は培養実験において極 
A.

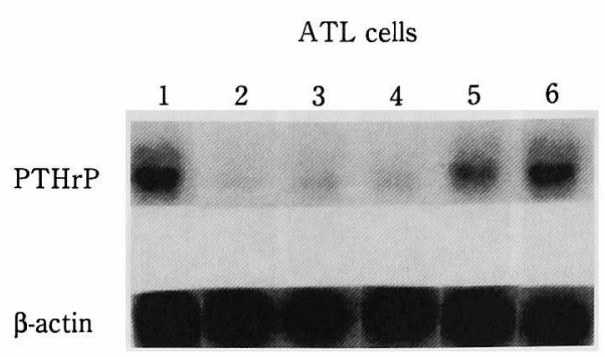

B.

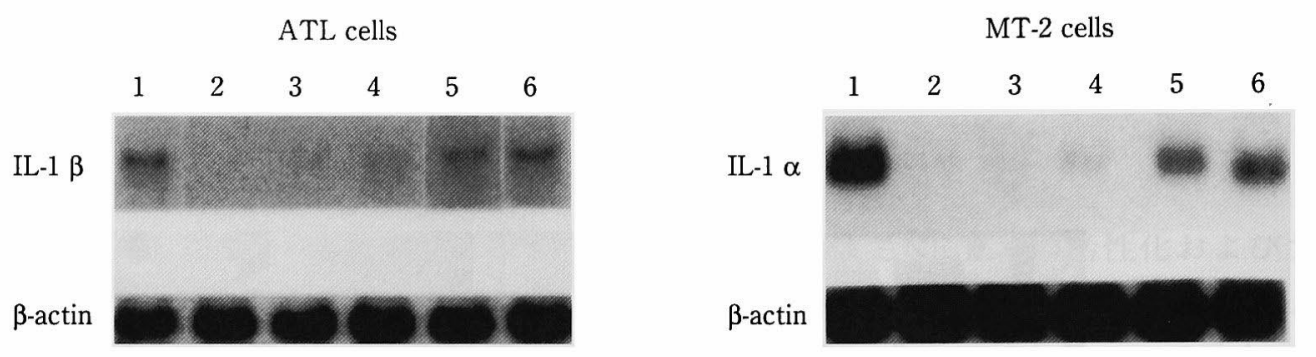

図 8. ICAM-1/LFA-1を介したCa依存性のATL細胞の凝集によるPTHrP mRNA(A), IL-1 mRNA（B）の発現

1. 抗体 (-), 2. EDTA添加, 3. 抗ICAM-1 抗体, 4. 抗LFA-1 抗体, 5. 抗LFA-3 抗体, 6. 抗CD25抗体

めて凝集し易いことを観察してきた. 一方， ATL細胞の增殖およびIL-I 産生が前述のごと く Ca濃度に依存する理由として，Caイオンを 必須とする細胞接着（凝集）が関与するのでは ないかと考え, ATL同士細胞接着, すなわち 細胞凝集とそれに伴う骨吸収刺激因子の産生の 可能性について検討した ${ }^{23)}$. まず, 肉眼的な観 察法であるCluster法を用いてATL細胞同士の 凝集を見ると, ATL細胞, 株細胞ではCa濃度 依存性に凝集度が強くなっているのに対し，マ イトーゲンであるPHA/PMA刺激でblast化し たT細胞ではかかる現象は認められず，ATL細 胞の凝集にはCaイオンの存在が必須であると 考えられた（図 7A). 細胞接着分子は細胞と 細胞, 細胞と細胞外基質の接着に関与し, 細胞 の機能を調節する. ATL細胞, 株細胞で様々 な接着分子の発現を検討すると, 通常の細胞と 異なりATL細胞, 株細胞では接着分子LFA-1 (lymphocyte function associated antigen-1) は
すでに活性化されていること，さらにそのリガ ンドであるICAM-1（intercellular adhesion molecule-1）も強く発現していることが判明した. 我々は, 前述したCa濃度依存性のATL細胞凝 集へのLFA-1/ICAM-1を介した細胞接着, さ らにこの細胞接着を介したPTHrP, IL- $1 \alpha, \beta$ の産生について検討した. 図 7Bに示すように, ATL細胞, 株細胞MT-2 細胞の凝集は, Ca イ オンのキレート剤であるEDTA，抗LFA-1抗 体あるいは抗ICAM-1抗体の添加で抑制され た.一方，この凝集はATL細胞で発現してい るLFA-3，CD25に対する抗体添加では抑制さ れず，Ca依存性のATL細胞同士の凝集にLFA1/ICAM-1を介した細胞接着が関与することが 確認された. ついで, LFA-1/ICAM-1を介し た細胞接着によるATL細胞および株細胞から のPTHrPおよびL-IのmRNAの発現について検 討した成績を図 8 に示す. 図 8AはATL細胞の PTHrP mRNA発現を示すがレーン 1 のPTHrP 


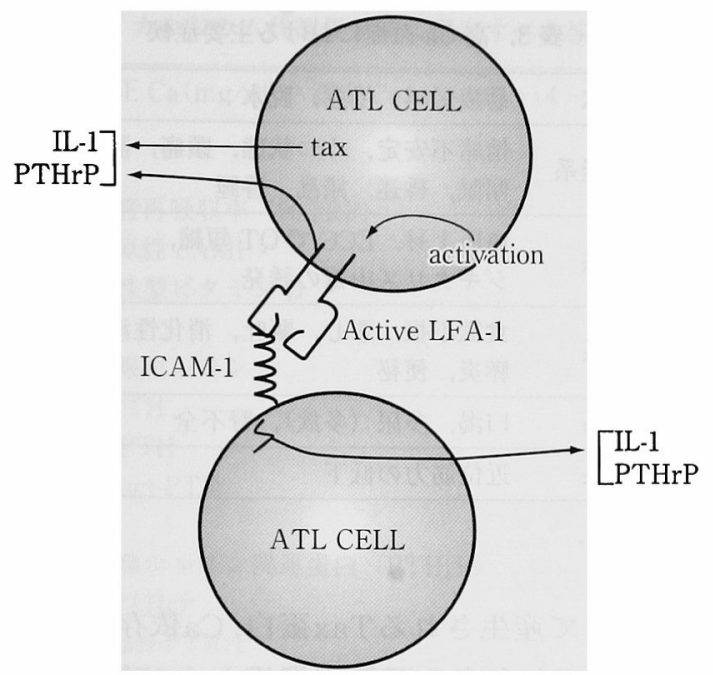

図 9. ICAM-1/LFA-1を介したATL細胞の同士細胞 接着によるPTHrP, IL-1産生機序

mRNA発現は, レーン $2,3,4$ に示すごとく， 凝集度を観察した時と同様にEDTAの添加，抗 LFA-1抗体, 抗ICAM-1抗体の添加で抑制され, 一方LFA-3，CD25に対する抗体添加ではこの 発現は抑制されなかった。図 8Bの左はATL細 胞のIL-1ßmRNA発現, 右は株細胞MT-2のIL$1 \alpha m R N A$ 発現を示す. IL- $1 \alpha, \beta m R N A の$ 発現 はPTHrP mRNA発現と同じようにEDTA，抗 LFA-1 抗体, 抗ICAM-1 抗体の添加で抑制さ れ，LFA-3，CD25に対する抗体添加で抑制さ れなかった。患者から採取したATL細胞培養 液中へのPTHrP, IL-1 $\beta$ 分泌をも検討したが, EDTA，抗LFA-1 抗体，抗ICAM-1 抗体の添 加でこれらの分泌は抑制され，LFA-3，CD25 に対する抗体添加では抑制されなかった.さら に, EDTA, 抗LFA-1 抗 体, 抗ICAM-1 抗 体 の添加はATL細胞の増殖を抑制することも明 らかとなり, LFA-1/ICAM-1を介した細胞接 着はATL細胞の増殖にも関与していた.

以上より, 図 9 のシェーマで示すごとく, Tax を介する経路に加えて, 細胞接着分子ICAM-1 /LFA-1を介したCa依存性のATL同士細胞接着 によってもATL細胞からのIL-I, PTHrPの産

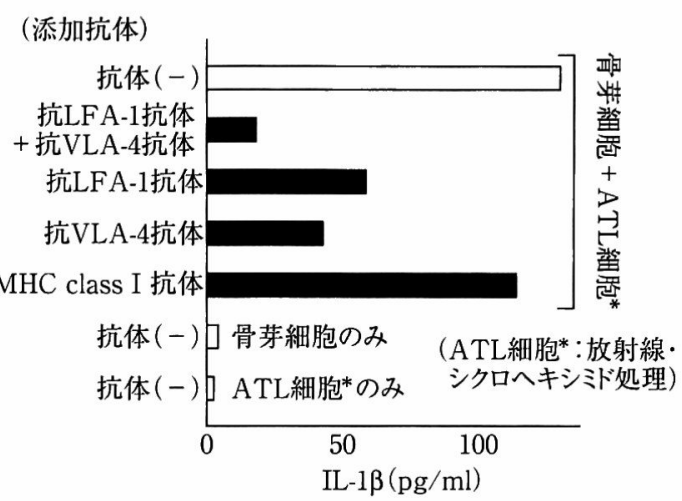

図10.ATL細胞と骨芽細胞の細胞接着を介した骨芽 細胞からのIL-1及産生

生が誘導されることが考えられる.また, LFA1/ICAM-1を介した細胞接着はATL細胞の増殖 を誘導するため, 前述のIL-1・PTHrPを介す る悪循環機構にCa依存性のATL同士の細胞接 着も関与する可能性がある.

（2）ATL細胞との接着を介した骨芽細胞から のIL-I 産生

骨芽細胞は様々なBRSFを産生し, 破骨細胞 の形成・活性化を誘導する，我々は，骨芽細胞 からのIL-1 $\beta, \mathrm{IL}-6$ の産生がT細胞と接着分子 を介した細胞接着で誘導されることを見出し た.すなわち，ヒト骨芽細胞は接着分子ICAM1, VCAM-1 (vascular cell adhesion molecule1)，LFA-3 発現しており，活性化T細胞の LFA-1, VLA-4，CD-2のそれぞれを介してT 細胞と細胞接着し,さらにそれぞれの細胞接着 は骨芽細胞からのIL-1 $\beta$, IL-6の産生を誘導す ることを見い出した ${ }^{24)}$.

上記の背景に基づき, 骨芽細胞とATL細胞 の接着および，それによる骨芽細胞からの BRSFの産生につき検討した。先ず，ATL細胞 は骨芽細胞と強度に接着し, この接着はICAMのレセプターである抗LFA-1抗体, VCAM-1 のレセプターである抗VLA-4抗体の添加で抑 制され，両者の同時添加でさらに抑制された。 このことより, ATL細胞は骨芽細胞と LFA-1/ 


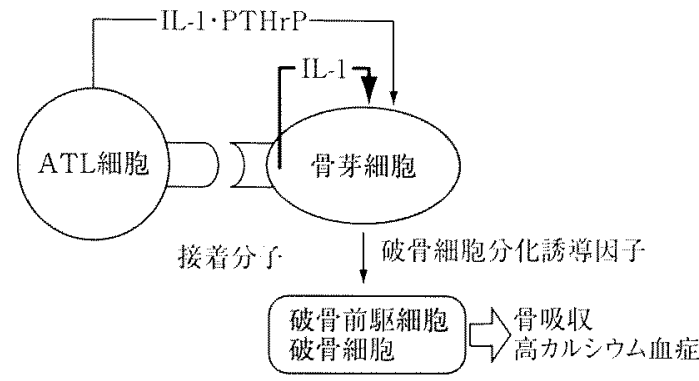

図11。ATL絸胞との接看による骨芽維胞からのIL-1 $\beta$ 童止機店

ICAM-1, VLA-4 (vary late antigen-4)/VCAM1を介して細胞接着することが確認された．次 ぎに,ATL細胞と接着した骨芽細胞からのIL-I 産生について検討した。ATL細胞を放射線お よびシクロヘキシミドで処理し，その機能，す なわちサイトカイン産生作用をブロックした ATL細胞を培養骨芽細胞に添加すると，図 10 のオープンカラムに示すように骨芽細胞からの IL-I $\beta$ 産生は増加した。このIL-I $\beta$ 産生は下段の コントロール抗体であるMHC class1抗体の添 加では影響を受けないが，抗LFA-1抗体，抗 VLA-4抗体の添加で抑制され，両者の同時添 加でさらに抑制された，すなわち，ATL細胞 はIFA-1/ICAM-1あるいはVLA-4/VCAM-1 を介して骨芽細胞と細胞接着することで骨芽細 胞からIL-I $\beta$ 産生を誘導し，骨吸収促進に関与 することが判明した（未発表デー夕）。図11の シェーマはすでに述べたATL細胞からのBRSF 産生に加えて, ATL細胞との接着により骨芽 細胞から産生されたIL-Iがオートクライン的 に，骨芽細胞に作用し，これも，最初に述べた 骨芽細胞を介する破骨細胞分化誘導因子の発 現ささらに骨吸収に関与することを示している。 上記の成績より，BRSFであるIL-1，PTHrPの 産生には複数の接着分子を介するATL細胞同 士あるいは骨芽細胞とATL細胞接着の関与し ていることも判明した。

以上, ATLの高Ca血症発症は, HTLV-I 感
表 3. 高 Ca 血症における主要症候

\begin{tabular}{|c|c|}
\hline 全身症状 & 易疲労感, 倦意, 脱水 \\
\hline 中枢神経系 & $\begin{array}{l}\text { 情緒不安定, うつ状態, 頭痛, 記憶障害, } \\
\text { 傾服, 昏迷, 錯乱, 昏睡 }\end{array}$ \\
\hline 循環器系 & $\begin{array}{l}\text { 血圧上㫒, ECG で QT 短縮, } \\
\text { ジギタリス中毒の誘発 }\end{array}$ \\
\hline 消化器系 & $\begin{array}{l}\text { 食欲不振, 恶心, 嘔吐, 消化性潰瘍, } \\
\text { 蓃炎, 便秘 }\end{array}$ \\
\hline 督尿路系 & 口渴, 多尿 (多飲), 堅不全 \\
\hline 筋骨格系 & 近位筋力の低下 \\
\hline
\end{tabular}

染によって産生されるTax蛋白, Ca依存性のIL1・PTHrPを介する悪循環機構および細胞接着 の関与等がからみ合って，他に類を見ない高頻 度に高Ca血症が発症するものと考えられる。

\section{3. 臨床症状・検查・治療}

\section{1）臨床症状}

血中Ca值が $12 \sim 13 \mathrm{mg} / \mathrm{d} 1$ 程度になると易疲労 感, 全身倦㤐感, 食欲不振などの不定愁訴的な 症状が出現する．更に高度の高Ca血症（13～15 $\mathrm{mg} / \mathrm{dl})$ では多尿による脱水とこれによる口渴 感・多飲が出現する，多尿は高Ca血症による 腎からの水再吸収の抑制, 腎での抗利尿ホルモ ン $(\mathrm{ADH})$ との拮抗作用による.この口渴・ 多飲は高Ca血症診断のきっかけとなるべき特 異な症状であることを銘記すべきである。この 他, 吐気, 嘔吐, 筋脱力も認められるようにな る.この時点ですでに精神症状も出現するが, $15 \mathrm{mg} / \mathrm{dl}$ 以上の高度の高Ca血症に至ると上記の 症状はいずれも増悪し，特に精神症状について は情緒不安定（イライラ感等）から始まって傾 眠，昏迷と進行し，高Ca血症に気がつかれな いままに放置されれば昏睡から死に至る事さえ ある。

強調すべきは, 原発性副甲状腺機能立進症の 場合と異なり，症状は急速に進行し迅速な治療 が必須である．高Ca血症関連症状でATLに特 
表 4. カルシウム代謝異常時に湘定すべき检查項目

血清補正 $\mathrm{Ca}(\mathrm{mg} / \mathrm{dl})=$ 測定 $\mathrm{Ca}(\mathrm{mg} / \mathrm{dl})+[4-\mathrm{Alb}(\mathrm{g} / \mathrm{dl})]$

血清 Pi

鳌尿細管再吸収率 (\%TRP)

尿中珡原性 cAMP

血清活性型ビタミン D

副甲状腺ホルモン

c-PTH

m-PTH

intact-PTH

副甲状腺ホルモン関連蛋白（PTHrP）

c-PTHrP

intact-PTHrP

有のものは無いが，本疾患では原病に対する有 効な治療法が無いことから，高Ca血症の管理 は極めて困難である．臨床症状を表 3 に示す. 症状のみから高Ca血症を診断する事は困難で あり，種々の病態と誤診される，特に，不定愁 訴, 吐気, 嘔吐は癌の末期症状, あるいは抗癌 薬の副作用として見逃されていることが多く， MAHなる病態の存在を念頭におき，進行した 悪性腫場の経過中には定期的に血中Ca值を測 定する事が重要である.

\section{2）検査}

高Ca血症を来したときに行うべき検查を表 4 に示す。

$\mathrm{Ca}$ 值検查に当たっては悪性腫瘍の末期には 低アルブミン血症が必発であるため，血中アル ブミン值による補正が必須であり，通常，表 4 の補正式が用いられる，因みに，高Ca血症そ のものがMAHのマーカーとなることを銘記し ていただきたい。

またPTHrP上昇が原因の場合には，PTHrP のN-端の構造及び生理的作用がPTHと極めて 類似しているところから，血中燐值，燐尿細管 再吸収率（\%TRP）の低下，血中・尿中cAMP 值の上昇等はHHM診断の参考となり,これが 認められ無い場合には逆に前述のサイトカイン
表 5. 孯性腫癔の高 Ca III症に対する治療

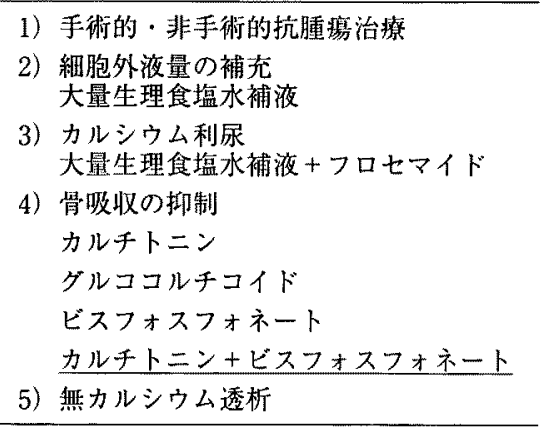

が原因のLOHを考えるべきであろう．ただし， HHMとLOHが判然としない症例の有ることは 前述の通りである。

\section{3）治療}

墨性腫瘍に伴う高Ca血症に対する治療の根 本は原疾患の治療にあることはいうまでもない が，進行期に見られ，前述の如く，急速に進行 するため，造血系悪性疾患を除けばほとんどの 場合，対症療法となる。治療法を表 5 に示す.

（1）一般療法

まず,試みるべきは生理食塩水の大量補液(約 $3 l /$ 日)，あるいはこれにループ利尿薬を加味す る基本的治療である．高Ca血症では脱水がほ ほ必発であり，これによる腎尿細管からのCa 再吸収増加がさらに高Ca血症を増悪させる。 本療法は，この悪循環を断つためと，ループ利 尿薬によるNa排泄に伴うCa排泄効果をねらっ たものである。この際，心肺機能に負担をかけ ない注意が肝要である。なお，同じ利尿薬でも サイアザイド系は腎からのCa再吸収作用があ り，その使用は禁忌である。

（2）骨吸収抑制薬

近年，強力な骨吸収抑制作用を有する薬剂と して各種のビスフォスフォネート製郕が新たに 開発され，市販されている.ビスフォスフォネー ト（ビスフォスフォン酸：bisphosphonate）は 本来, 生体内にあるピロリン酸が強力な骨吸収 抑制作用を有するアナログに変わったものであ 


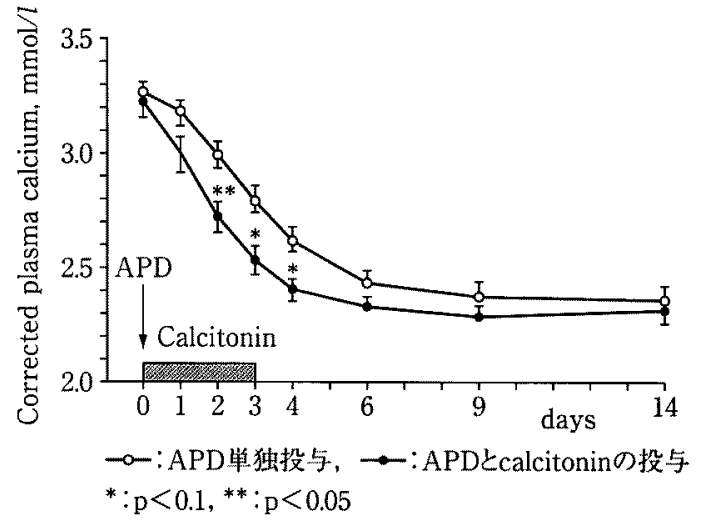

図12、高Ca血症に対するカルシトニン・ビスフォス フォネート併用療法の効果

る. 本剤の効果は極めて強力であり，高Ca血 症の是正とともに，意識障害，食欲不振，恶心， 嘔吐, 脱力感, 骨痛等の改善を認め, 副作用に ついてとくに取り上げるべきものは無い. 通常, 一回の静脈内投与後, 約 2 週間まで血清Ca值 および自覚症状の改善が持続し, 悪性腫瘍の高 Ca血症に対する極めて有用な薬剤である.唯 一の欠点はCa值が下降するまでに 3〜 4 日間を 要することであり，この欠点を補うため，カル シトニンの速効性を利用した併用療法が試みら れている. 投与法は初回投与時にカルシトニン 製剈（エルシトニン40単位を 1 日 2 回）を筋注 ・点滴する.カルシトニン・ビスフォスフォ ネート併用療法の有効率はほぼ100\%であり， 従来, 用いられてきたカルシトニン・グルココ ルチコイド併用療法は, カルシトニン・ビス フォスフォネート併用療法に取って代わられ た. 図12はビスフォスフォネートの一つである APD (pamidronate) の単独投与に比し, カル シトニン併用療法が, 上り有効であることを示 したものである25. な㧍，治療の目的はあくま で症状の改善にあり，臨床の現場でしばしば見 られる様に, 無理にCa值を正常值に戻す必要 は無い。
まとめ

ATLにおいて極めて高頻度に高Ca血症を合 併する機序につき, 我々の長年にわたる研究成 果を紹介し，加えて，悪性腫湢全般における高 Ca血症の基礎と臨床についても簡略に概説し た.

1）悪性腫㾇に高Ca血症が高頻度に出現し, 子後にも影響することを認識すべきである (QOL : quality of lifeの観点からも重要).

2）高Ca血症発症因子の主なものはPTHrPの ほか, IL-I, IL-6, TNF, TGF等のサイトカ インである。

3）ATLに極めて高Ca血症が高頻度に発症す る機序としては, HTLV-I 感染で発現するTax 蛋白のIL-I - PTHrP産生への関与, 高Ca血症に よるIL-I ・ PTHrP産生を介する悪循環機構の存 在, $\mathrm{IL}-1$ の破骨細胞への直接効果, $\mathrm{Ca}$ 依存性 細胞接着の関与等が考えられる.

4）悪性腫瘍に伴う高Ca血症の症状には不定 愁訴が多く, 急速に進行し, 特に精神症状の增 悪には注意を要する。

5）一般的治療法としては, 生理食塩水の大 量投与の他に, カルシトニン・ビスフォスフォ ネート併用療法が極めて有効である.

\section{謝辞}

本報告におけるATLに関する知見は全て, 産業医科大学 第一内科の諸君の長年にわたる努力の結晶であり，謝辞を 述べるとともに，宿題報告に指定された栄誉を被らととも に分かち合いたい．

\section{文献}

1）木村 哲，他：がん患者における高カルシウム血症の 治療に関する研究. 昭和60年度厚生省がん研究助成金 による研究報告集. pp338-342，1985.

2) Wong BR, et al: Trance is a novel ligand of the tumor necrosis factor receptor family that activates c-Jun $\mathrm{N}$ terminal kinase in $\mathrm{T}$ cells. J Biol Chem $272: 25190$ 25194, 1997. 
3) Anderson DM, et al: A homolog of the TNF receptor and its ligand enhance $T$-cell growth and dendric-cell function. Nature 390:175-179, 1997.

4) Yasuda $\mathrm{H}$, et al: Osteoclast differentiation factor is a ligand for osteoprotegerin/osteoclastogenesis-inhibitory factor and identical to TRANCE/RANKL. Proc Natl Acad Sci USA 95 : 3597-3602, 1998.

5) Lacey DL, et al: Osteoprotegerin ligand is a cytokine that regulates osteoclast differentiation and activation. Cell $93: 165-176,1998$.

6) Jimi $\mathrm{E}$, et al: Interleukin 1 induces multinucleation and bone-resorbing activity of osteoclasts in the absence of osteoblast/stromal cells. Exp Cell Res 247 : 84-93, 1999.

7) Kobayasi $K$, et al: Tumor necrosis factor $\alpha$ stimulates osteoclast differentiation by a mechanism independent of the ODF/RANKL interaction. J Exp Med $191: 275^{-}$ 286,2000 .

8) Motokura $T$, et al: Parathyroid hormone-related protein in T-cll leukemia-lymphoma. Ann Intern Med 111: 484-488, 1989.

9) Watanabe $T$, et al : Constitutive expression of parathyroid hormone-related protein gene in human $\mathrm{T}$ cell leukemia virus type I (HTLV-I) carriers and adult T cell leukemia patients that can be transactivated by HTLVI tax gene. J Exp Med 172: 759-765, 1990.

10) Ikeda $\mathrm{K}$, et al : Transcription of parathyroid hormonerelated in protein from the human is activated through a cAMP dependent pathway by prostaglandin $E_{1}$ in HTLV-I-infected T cells. J Biol Chem 268: 1174-1179, 1993.

11) Dittmer J, et al:Interaction of human T-cell lymphotropic virus type-I Tax, Ets, and Spl in transactivation of the PTHrP P2 promotor. J Biol Chem 272 : 49534958, 1997.

12) Ikeda $\mathrm{K}$, et al : Interleukin-2 increases production and parathyroid hormone-related peptide of HTLV-I-infected $\mathrm{T}$ cells : Possible role in hypercalcemia associated with adult T-cell leukemia. Endocrinology 132:25512556, 1993.

13) Mori N, et al: Enhancing effect of interleukin-2 on production of parathyroid hormone-related protein by adult $\mathrm{T}$ cell leukemia cells. Jpn J Cancer Res 84 : 425$430,1993$.
14) Guise TA, et al : Evidence for causual role of parathyroid hormone-related protein in the pathogenesisis of human breast cancer-mediated osteolysis. J Clin Invest 98 : 1544-1549, 1996

15) Fujihira $T$, et al : Evidence of bone resorption-stimulating factor in adult $\mathrm{T}$ cell leukemia. Jpn J Clin Oncol. $15: 385-391,1985$.

16) Shirakawa $F$, et al : Production of bone resorbing activity corresponding to interleukin-1 $\alpha$ by adult T-cell leukemia cells in humans. Cancer Res 48:4284-4287, 1988.

17) Mori $N$, al et: Transactivation of the interleukin-1 $\alpha$ gene promotor by human $T$ cell leukemia virus type-I Tax in T cell. Blood $84: 1688-1689,1994$.

18) Mori $N$, et al : Transactivation of the interleukin-1 $\alpha$ promotor by human T-cell leukemia virus type-I and typeII Tax proteins. Blood $87: 3410-3417,1996$.

19) Tsukada J, et al: Human $T$ cell leukemia virus type-I Tax transactivates the promortor of human prointerleukin $1-\beta$ gene through association with two transcription factors, nuclear factor-interleukin-6 and Spi-1. Blood $90: 3142-3153,1997$.

20) Shirakawa F, et al : Calcium dependency in the growth of adult T-cell leukemia cells in vitro. Cancer Res 46 658-661, 1986.

21) Tanaka $Y$, et al : Calcium dependency of the production of interleukin-1 and the expression of interleukin-1 re ceptors of human adult T-cell leukemia cells in vitro Cancer Res 50 : 4344-4348, 1990.

22) Shirakawa $F$, et al: Autocrine stimulation of interleukin- $1 \alpha$ in the growth of adult T cell lukemia (ATL) cells. Cancer Res 49: 1143-1147, 1989.

23) Wake $A$, et al: Calcium dependent homotypic adhesion through LFA-1/ICAM-1 induces IL-1 and PTHrP production on adult T-cell leukemia cells in vitro. Blood 86 : 2257-2267, 1995.

24) Tanaka $Y$, et al : Osteoblasts are regulated by the cellular adhesion through ICAM-1 and VCAM-1. J Bone Miner Res 10 : 1462-1469, 1995.

25) Tieboud D, et al: Fast and effective treatment of malignant hypercalcemia-combination of supositories of calcitonin and a single use of 3-amino 1-hydroxypropyridine1-bisphosphonate. Arch Intern Med 150:2125-2128, 1992. 